\title{
SOME HEALTH EFFECTS DUE TO CHRONIC OCCUPATIONAL EXPOSURE TO CYANIDE
}

\author{
By \\ ${ }^{1}$ Emara AM, ${ }^{1}$ Abbas AB,${ }^{2}$ Sabry D, and ${ }^{1}$ Manawil M \\ ${ }^{1}$ Department of Occupational \& Environmental Medicine, ${ }^{2}$ Department of Biochemistry, \\ Faculty of Medicine, Cairo University.
}

\begin{abstract}
Introduction: Exposure to cyanide is encountered in many industries as in Case Hardening and Electroplating. Chronic exposure to cyanide is associated with some health effects including its effect on thyroid gland. Aim of work: To study the health effects due to chronic occupational exposure to cyanide with special emphasis on the thyroid gland. Materials and Methods: This study was conducted on 56 workers exposed to cyanide in case hardening and electroplating industry. Their age ranged between 36 and 59 years with a mean of $46.96 \pm 5.51$ years. They are exposed to cyanide from 4 to 31 years with a mean of $19.86 \pm 8.53$ years. They were compared with 60 workers not exposed to cyanide as a control group, Their age ranged between (30-60) years with a mean of 45.76 and S.D. \pm 11.81 . Hydrogen cyanide was measured in air of workplace environment. Serum thiocyanate serum and thyroid hormones $\left(\mathrm{T}_{3}, \mathrm{~T}_{4}\right.$, and $\left.\mathrm{TSH}\right)$ were measured. Results: The serum thiocyanate levels showed highly statistically significant difference among exposed workers when compared to the control. A highly statistically significant lower serum levels of $\mathrm{T}_{3}$ and $\mathrm{T}_{4}$ among the exposed group, and higher serum levels of TSH compared to the control group. Serum TSH showed a statistically significant positive correlation with serum thiocyante among the exposed workers, a statistically significant negative correlation as regards $\mathrm{T}_{3}$, and a negative correlation between TSH and $\mathrm{T}_{4}$ but it is not statistically significant. Conclusion: Cyanide exposure is associated with decrease in thyroid functions but not clinically detected.
\end{abstract}

Key words: Cyanide, Chronic health hazards, Thyroid hormones, $\mathrm{T}_{3}, \mathrm{~T}_{4}, \mathrm{TSH}$. 


\section{Introduction}

Cyanide has gained historical notoriety as a poison used with intent to cause fatality. Its occurrence in industry is confined to a small number of uses in a relatively narrow range of industries, including the manufacture of nylon and in electroplating (Cummings, 2004).

Cyanide exposure can occur during the process of electroplating as it requires cyanide salts. Inhalation, dermal and ocular exposures of cyanide may occur (Lizarralde et al., 1997).

Chronic effects of low exposure to cyanide include conjunctival irritation from direct contact and skin ulceration. Thyroid gland enlargement has been described, particularly in areas where iodine intake is low. Residual symptoms after chronic exposure include a bitter almond taste in the mouth and headache.

It is difficult to measure hydrogen cyanide in air. To accurately assess exposure, it may be necessary to measure several different cyanide compounds, since $\mathrm{HCN}$ can be unstable in the environment. Biologic monitoring may be performed by measuring blood or urine thiocyanate levels (Beckett, 1998).
There are a number of reports on the possible cyanide and thiocyanate-related etiology of thyroid disorders. Thus, as thiocyanate acts as a competitive inhibitor of iodide accumulation in the thyroid, it could produce goiter and/or hypothyroidism (Sousa et al., 2002).

Tobaccocontainscyanide, sotobacco smoking increases the risk of goiter and Grave's disease. In a large population study, there was a high occurrence of thyroid multinodularity and subclinical hypothyroidism among tobacco smokers. The observed associations seem explainable by the blocking of iodine uptake and organification in the thyroid by thiocyanate, a degradation product of cyanide in tobacco smoke (Knudsen et al., 2002).

\section{Aim of the work}

To study health effects due to chronic occupational exposure to cyanide with special emphasis on the thyroid gland.

\section{Materials and Methods}

\section{Subjects}

The study was carried out in a unit for heat treatment (including case hardening and electroplating) in a factory for automobile manufacturing and in a unit for electroplating belonged 
to a big institute for communication tools. This study was conducted on 56 male workers exposed to cyanide in case hardening and electroplating industry. Their age ranged between 36 and 59 years with a mean of $46.96 \pm$ 5.51 years. They are exposed to cyanide from 4 to 31 years with a mean of 19.86 \pm 8.53 years. They were compared with 60 male workers not exposed to cyanide as a control group; they were chosen from different locations so as to match the exposed workers in age, sex, special habits (specially smoking habit) and socioeconomic status. Their age ranged between (30-60) years with a mean of 45.76 and S.D. \pm 11.81 .

\section{Laboratory analysis:}

\section{1- Serum Thiocyanate analysis methodology}

The method used for standardization of thiocyanate measurements was the WHO Monica Project (http://www.thl. fi/publications/monica/manual/part3/ iii-3.htm).

\section{2- Thyroid hormones analysis methodology}

Free T3 triiodothyronine, Free T4 tetraiodothyronine, and TSH thyroid stimulating hormone.
Using in vitro diagnostic use in the quantitative determination of thyroid hormones in serum using ACS: 180 Automated Chemiluminescence Systems.

\section{Environmental Assessment:}

\section{Hydrogen cyanide 6010}

OSHA: 10 ppm (skin)

NIOSH: STEL 4.7 ppm

ACGIH: C 10 ppm (skin) $(1$ ppm = $1.105 \mathrm{mg} / \mathrm{m3} @ \mathrm{NTP})$

Properties: gas; $\mathrm{BP} 26^{\circ} \mathrm{C}$; vapor density 0.93 ( air $=1.00$ ); ( liq) $0.69 \mathrm{~g} /$ $\mathrm{mL} @ 20^{\circ} \mathrm{C}$; VP $82.7 \mathrm{kPa}(620 \mathrm{~mm} \mathrm{Hg})$ @ $20^{\circ} \mathrm{C}$; explosive range 5 to $40 \% \mathrm{v} / \mathrm{v}$ in air

Synonyms: hydrocyanic acid, prussic acid, formonitrile

\section{Sampling}

Sampler: SOLID SORBENT TUBE (soda lime, 600mg/ $200 \mathrm{mg}$ ) FLOW RATE: 0.05 to $0.2 \mathrm{~L} / \mathrm{min}$. VOL- MIN: 2 L@ 5 ppm- MAX: 90 L SHIPMENT: routine

Sample Stability: at least 2 weeks @ $25^{\circ} \mathrm{C}$

Blanks: 2 to 10 field blanks per set 


\section{Measurement technique:}

Spectrophotometry,

Visible absorption analyte: cyanide ion complex

(http://www.cdc.gov/niosh/ docs/2003-154/pdfs/6010.pdf).

\section{Statistical Data Analysis}

Collected data were coded and arranged to facilitate its manipulation.

Data were analyzed and computed using statistical package for social sciences (SPSS) version 11. Simple statistics as frequency, arithmetic mean and standard deviation were used.
- The unpaired student " $t$ " test is used for comparing means of two groups.

A "P" value of 0.05 was considered the limit below which the difference of the values would be statistically significant. A "P" value of 0.001 was considered the limit below which the difference of the values would be statistically highly significant.

- ANOVA (analysis of variance) for comparing three or more means.

- Pearson correlation: it is used when the goal is merely to establish a relationship (or association) between two measures (Bland, 2000). 


\section{Results}

Table (1): Mean value of serum thiocyanate (SCN) levels among cyanideexposed workers and control group.

\begin{tabular}{|c|c|c|c|c|}
\hline & $\begin{array}{c}\text { Exposed } \\
\text { Mean } \pm \mathrm{SD}\end{array}$ & $\begin{array}{c}\text { Control } \\
\text { Mean } \pm \mathrm{SD}\end{array}$ & T-test & P. value \\
\hline SCN $(\mu \mathrm{mol} / \mathrm{L})$ & $246.7 \pm 75.26$ & $105 \pm 9.44$ & 14.47 & $<0.001^{* *}$ \\
\hline
\end{tabular}

**: Highly significant

A statistically significant higher level of serum thiocyanate ( $\mathrm{SCN}$ ) was detected among cyanide exposed group compared to the level of the control group.

Table (2-a): Mean values of serum thiocyanate (SCN) levels of exposed and control group as regards smokers and non-smokers.

\begin{tabular}{|c|c|c|c|c|}
\hline $\begin{array}{c}\text { SCN } \\
(\boldsymbol{\mu ~ m o l} / \mathbf{L})\end{array}$ & $\begin{array}{c}\text { Exposed } \\
\text { Mean } \pm \text { SD }\end{array}$ & $\begin{array}{c}\text { Control } \\
\text { Mean } \pm \text { SD }\end{array}$ & T-test & P value \\
\hline Smokers & $\begin{array}{c}256.53 \pm 66.43 \\
(\mathrm{n}=34)\end{array}$ & $\begin{array}{c}110.25 \pm 6.62 \\
(\mathrm{n}=40)\end{array}$ & 12.79 & $<0.001 * *$ \\
\hline Non-smokers & $\begin{array}{c}231.55 \pm 86.62 \\
(\mathrm{n}=22)\end{array}$ & $\begin{array}{c}94.5 \pm 3.59 \\
(\mathrm{n}=20)\end{array}$ & 7.41 & $<0.001 * *$ \\
\hline
\end{tabular}

**: Highly significant

A statistically significant higher level of serum thiocyanate ( $\mathrm{SCN}$ ) was found among the exposed smokers and non-smokers when compared to the control group. 
Table (2-b): Mean values of serum thiocyanate (SCN) levels of smokers and non-smokers within the exposed and the control groups.

\begin{tabular}{|c|c|c|c|c|}
\hline $\begin{array}{c}\text { SCN } \\
(\mu \mathrm{mol} / \mathrm{L})\end{array}$ & $\begin{array}{c}\text { Smokers } \\
\text { Mean } \pm \mathrm{SD}\end{array}$ & $\begin{array}{c}\text { Non-smokers } \\
\text { Mean } \pm \mathrm{SD}\end{array}$ & T-test & P. value \\
\hline Exposed & $\begin{array}{c}256.53 \pm 66.43 \\
(\mathrm{n}=34)\end{array}$ & $\begin{array}{c}231.55 \pm 86.62 \\
(\mathrm{n}=22)\end{array}$ & 1.22 & N.S. \\
\hline Control & $\begin{array}{c}110.25 \pm 6.62 \\
(\mathrm{n}=40)\end{array}$ & $\begin{array}{c}94.5 \pm 3.59 \\
(\mathrm{n}=20)\end{array}$ & 9.91 & $<0.001^{* *}$ \\
\hline
\end{tabular}

N.S.: Non significant

**: Highly significant

A statistically significant higher level of serum thiocyanate $(\mathrm{SCN})$ was found among smokers compared to the non-smokers among the control group. Although the level of SCN was higher among the exposed smokers when compared to exposed non smokers but not to the statistical significance level.

Table (3): Serum concentrations of thyroid functions (T3, T4, TSH) measured among cyanide exposed workers and control group.

\begin{tabular}{|c|c|c|c|c|}
\hline & $\begin{array}{c}\text { Exposed group } \\
\text { Mean } \pm \text { S.D. }\end{array}$ & $\begin{array}{c}\text { Control group } \\
\text { Mean } \pm \text { S.D. }\end{array}$ & t-test & P value \\
\hline T3 & $131.82 \pm 27.68$ & $176.36 \pm 20.21$ & 9.8 & $<0.001^{* *}$ \\
\hline T4 & $9.48 \pm 2.79$ & $11.3 \pm 0.7$ & 4.89 & $<0.001^{* *}$ \\
\hline TSH & $1.03 \pm 0.4$ & $0.67 \pm 0.36$ & -4.82 & $<0.001 * *$ \\
\hline
\end{tabular}

**: Highly significant

There are high statistically significant differences in comparing exposed and control groups as regards thyroid functions. 
Table (4): Pearson correlation between serum thiocyanate (SCN) and each of the serum thyroid parameters (T3, T4, TSH) measured among the exposed workers (56 workers).

\begin{tabular}{|c|c|c|c|c|}
\hline & & $\mathrm{T} 3$ & $\mathrm{~T} 4$ & $\mathrm{TSH}$ \\
\hline \multirow{3}{*}{$\mathrm{SCN}$} & r value & -0.64 & -0.25 & 0.52 \\
\cline { 2 - 5 } & P value & $<0.001 * *$ & N.S. $(0.063)$ & $<0.001 * *$ \\
\hline
\end{tabular}

NS: Non significant

**: Highly significant

The relation of thyroid parameters ( $\mathrm{T} 3, \mathrm{~T} 4$, and $\mathrm{TSH})$ to serum thiocyanate (SCN) level showed a highly statistically significant positive correlation as regards TSH. A highly statistically significant negative correlation $(\mathrm{P}<0.001)$ was found between SCN and T3, while a negative correlation was found with T4 but not to a significant level.

Table (5-a): Environmental measurement of hydrogen cyanide (HCN) in air

\begin{tabular}{|l|c|}
\hline Points of measurement & HCN (ppm) \\
\hline In automobile factory & \\
\hline A- Case hardening furnace (area 1) & 9.1 \\
\hline B- Another furnace of case hardening (area 2) & 8.7 \\
\hline C- Electroplating & 6.7 \\
\hline D- Entrance & 4.2 \\
\hline In communication tools factory & \\
\hline A- Electroplating & 7.1 \\
\hline B- Entrance & 4.7 \\
\hline
\end{tabular}




\section{Discussion}

This study was carried out in a unit for heat treatment (including case hardening and electroplating) in a factory for automobile manufacturing and in a unit for electroplating belonged to a factory for communication tools. The study was conducted on 56 male shift workers exposed to cyanide salts during their work. A control group consists of 60 male subjects not exposed to cyanide.

The smoking habit shows non statistically significant difference between the exposed and the control group as regards the distribution of smokers to non-smokers ( $p=0.56)$. So, they are homogenous groups as regards the smoking habit distribution within each group.

Serum thiocyanate $(\mathrm{SCN})$ showed a statistically significant higher level among cyanide exposed group compared to the levels of the control group (Table1). The mean SCN concentration of these workers was $246.7 \pm 75.26$ $\mu \mathrm{mol} / \mathrm{L}$, which was significantly higher than that of control group $(105 \pm 9.44$ $\mu \mathrm{mol} / \mathrm{L})$. This is concomitant with the results found by Banerjee et al., (1997) who conducted their study on workers dealing with cyanide compounds in an electroplating process of a cable industry, and found that the mean SCN concentration of these employees was $316 \pm 15 \mu \mathrm{mol} / \mathrm{L}$. This was significantly higher than that of control group $(90.8 \pm$ $9.02 \mu \mathrm{mol} / \mathrm{L}$ ). In electroplating industry, workers were found to be exposed to enormous amounts of cyanide (Grant \& Blumenstock, 2000).

A statistically significant higher level of serum thiocyanate (SCN) was found among the exposed compared to the control smokers (Table 2a). This is due to additional exposure of cyanide from tobacco smoke. This finding coincided with the work done by ElAzim et al., (2002).

The same finding was encountered among the non-smokers. The blood levels of SCN in the non-smoker exposed workers were higher than those in the non-smoker control subgroup by a statistically significant value as in Table (2-a). This emphasizes the effect of cyanide exposure on serum SCN as a biological indicator. Biological monitoring techniques potentially offer a more useful indicator of $\mathrm{CN}$ exposure than does environmental monitoring, because biological parameters are expectedly more directly associated with the adverse health effects and 
reflect all routes of $\mathrm{CN}$ exposure (Hoerger et al., 1999).

A statistically significant higher level of serum thiocyanate ( $\mathrm{SCN}$ ) was detected among smokers compared to non-smokers control group. Although the level of SCN was higher among the exposed smokers when compared to exposed non smokers but not to the statistical significance level Table (2b). Pesce LD, 1993 mentioned that hydrogen cyanide is present in human being's blood and that people who smoke or consume vegetables having relatively high cyanide content, may have slightly higher blood levels.

As regards thyroid functions (serum T3, T4, TSH), a high statistically significant lower serum levels of $\mathrm{T} 3$ and T4 among the exposed group, and higher serum levels of TSH compared to the control group (Table3). This is in agreement with that found by Metwally et al. (2001) on evaluating thyroid hormones among workers dealing with cyanide compounds in electroplating process of a factory manufacturing refrigerators.

The effect of work-place cyanide exposure on the thyroid parameters was studied by the correlation between serum SCN levels and levels of thyroid hormones. This revealed a statistically significant positive correlation $(\mathrm{r}=0.52$, $\mathrm{P}<0.01$ ) between SCN and TSH. While on correlating the thyroid hormones to SCN, we found a statistically significant negative correlation as regards $\mathrm{T} 3(\mathrm{r}=$ - 0.64, $\mathrm{P}<0.01$ ), but a non-significant negative correlation as regards $\mathrm{T} 4 \mathrm{(r}$ $=-0.25, \mathrm{P}=0.063$ ) (Table 4). This is concomitant with Banerjee et al., (1997) as regards TSH correlation to SCN levels among cyanide exposed workers. They found that the TSH was positively correlated $(\mathrm{r}=0.354, \mathrm{P}<0.05)$ with SCN concentration among the exposed group. They also found that serum T4 level was negatively correlated $(\mathrm{r}=$ $0.363, \mathrm{P}<0.05)$ to SCN and T3 level was negatively correlated with SCN but it was not statistically significant $(\mathrm{r}=$ $0.245, \mathrm{P}>0.05)$.

These findings can also be explained by the fact that serum TSH is the investigation of choice and that a high TSH level confirms primary hypothyroidism (Kumar and Clark, 2005). They also stated that a low free T4 level confirms the hypothyroid state.

\section{Recommendations}

It is recommended to control cyanide exposure in the workplace by: 
1. Substitution of substance (cyanide) by another less toxic one.

2. Engineering control measures.

3. Administrative measures not allowing the same workers to permanently work in close vicinity to cyanide in case of hardening or electroplating processes as we saw that some workers work on the case of hardening furnace for about 25 years.

4. Enclosure of the offending processes including case hardening and electroplating specially the first one which represents the higher exposure to cyanide.

5. Proper ventilation of the workplace.

6. Encourage the use of personal protective measurements in the form of respirators.

7. Health education should be given to workers by various methods, they should be educated not to eat, have rest or sleep in the units of work.

\section{Acknowledgment}

I am grateful to all the examined group of this work for their cooperation and great help.

I am also grateful to the whole stuff members of the Department of Occupational and Environmental Medicine ,Cairo University, who have contributed in any way to this work; I owe them my warmest thanks and appreciation.

\section{References}

1. Banerjee KK, Bishayee A and Marimuthu P (1997): Evaluation of cyanide exposure and its effect on thyroid function of workers in a cable industry. JOEM; 39 (3): $258-260$.

2. Beckett WS (1998): Chemical asphyxiants. In: Environmental and Occupational Medicine. 3rd ed. By: Rom WN. Lippincott-Raven publishers, Philadelphia; 44: 657-665.

3. Bland M, (2000): An introduction to medical statistics. Oxford University press. 3rd ed.

4. Cummings TF (2004): The treatment of cyanide poisoning. Oxford Journals, Occupational Medicine (Lond); 54(2): 82-85.

5. El-Azim SA, Selim AA and Ghaleb SS (2002): Neurobehavioral effects in workers exposed to cyanide. The Journal of Legal Medicine and Forensic Sciences.;14(2): 50-65.

6. Grant C and Blumenstock JS (2000): Cyanide alert. New Jersey Poison Information and Education System.

7. Heliövaara M et al. (1981): Serum thiocyanate concentration and cigarette smoking in relation to overall mortality and to deaths from coronary heart disease and lung cancer. J Chron Dis. 34:305-311.

8. Hoerger DF, Rampy WL, and Rausch AD, (1999): Bioactivation of cyanide to cyanate, relevance to neurological disease in humans subsisting on cassava. Toxicol. Sci.; 50 (2): 228-235.

9. http://www.cdc.gov/niosh/docs/2003-154/ pdfs/6010.pdf 
10. http://www.thl.fi/publications/monica/manual/ part3/iii-3.htm

11. Knudsen N, Bülow I, Laurberg P, Perrild H, Ovesen L and Jørgensen T (2002) : High occurrence of thyroid multinodularity and low occurrence of subclinical hypothyroidism among tobacco smokers in a large population study. J Endocrinol; 175: 571-576.

12. Kumar $P$ and Clark M (2005): Endocrine disease. 6th ed. Elsevier Saunders; 18: 10351100 .

13. Lizarralde SM, Wake B, Thompson V and Weisman RS (1997): Jewelers. In: Occupational, Industrial and Environmental Toxicology. By:
Greenberg MI, Hamilton RJ and Phillips SD. 1ST ed. Mosby-Year Book; 20: 153-169.

14. Metwally FM, El-Safty AMK and El-Kholy FM (2001): Endocrinal, liver, and kidney dysfunction in chronic occupational exposure to cyanides. Egyptian Journal of Occupational Medicine; 25(2): 219-229.

15. Pesce LD (1993): Kirk-Othmer Encycl Chem Technol 4th ed. Kroschwitz JI, ed. NY, NY: John Wiley and Sons 7: 758-82.

16. Sousa AB, Soto-Blanco B and Guerra JL, (2002): Does prolonged oral exposure to cyanide promote hepatotoxicity and nephrotoxicity? Toxicology; 174: 87-95. 